\title{
Inhibitory Effects of (-)-Epigallocatechin-3-gallate on Esophageal Cancer
}

\author{
Liu-Xiang Wang ${ }^{1}$, Yun-Long Shi ${ }^{2}$, Long-Jie Zhang ${ }^{3}$, Kai-Rong Wang ${ }^{3}$, Li-Ping Xiang ${ }^{4}$, \\ Zhuo-Yu Cai ${ }^{2}$, Jian-Liang Lu ${ }^{2}$, Jian-Hui Ye ${ }^{2}$, Yue-Rong Liang ${ }^{2, *}$ and Xin-Qiang Zheng ${ }^{2, *}$ \\ 1 China-US (Henan) Hormel Cancer Institute, No. 127, Dongming Road, Zhengzhou 450008, Henan, China; \\ lxwang@hci-cn.org \\ 2 Tea Research Institute, Zhejiang University, Hangzhou 310058, China; 11516051@zju.edu.cn (Y.-L.S.); \\ 21716160@zju.edu.cn (Z.-Y.C.); jllu@zju.edu.cn (J.-L.L.); jianhuiye@zju.edu.cn (J.-H.Y.) \\ 3 Ningbo Huangjinyun Tea Science and Technology Co. Ltd., Yuyao 315412, China; \\ zhanglongjie0701@163.com (L.-J.Z.); wkrtea321hjytea@163.com (K.-R.W.) \\ 4 National Tea and Tea Product Quality Supervision and Inspection Center (Guizhou), Zunyi 563100, China; \\ xlping6009@126.com \\ * Correspondence: yrliang@zju.edu.cn (Y.-R.L.); xqzheng@zju.edu.cn (X.-Q.Z.); \\ Tel.: +86-571-8898-2704 (Y.-R.L. \& X.-Q.Z.)
}

Academic Editor: Saverio Bettuzzi

Received: 5 February 2019; Accepted: 4 March 2019; Published: 8 March 2019

\begin{abstract}
There is epidemiological evidence showing that drinking green tea can lower the risk of esophageal cancer (EC). The effect is mainly attributed to tea polyphenols and their most abundant component, (-)-epigallocatechin-3-gallate (EGCG). The possible mechanisms of tumorigenesis inhibition of EGCG include its suppressive effects on cancer cell proliferation, angiogenesis, DNA methylation, metastasis and oxidant stress. EGCG modulates multiple signal transduction and metabolic signaling pathways involving in EC. A synergistic effect was also observed when EGCG was used in combination with other treatment methods.
\end{abstract}

Keywords: tea polyphenols; anticancer; angiogenesis; DNA methylation; metastasis; oxidant stress

\section{Introduction}

Esophageal cancer (EC) is a frequently diagnosed cancer of the digestive tract, especially in men, ranking seventh in term of incidence and sixth in mortality rate worldwide. There were about 572,000 new cases and 509,000 deaths around the world in 2018 [1]. China has the highest EC incidence [2]. The prognosis of EC is quite poor, because most patients present with advanced disease. Although great progress has been made in the diagnosis and treatment of cancer, the mortality rate of EC is still very high, and the worldwide average 5-year survival rate of patients with EC is about $15 \%$ to $25 \%$ [3]. Among EC patients, most of them are diagnosed as esophageal squamous cell carcinoma (ESCC) or esophageal adenocarcinoma (EAC), and these two main subtypes account for more than $95 \%$ of all the malignant esophageal tumors [4]. Currently, surgery, chemotherapy, radiotherapy or a combination of modalities are still the main methods used in the treatment of EC. However, these methods have multiple side effects which certain patients are unable to tolerate. Dietary polyphenols were reported to have suppressive effects on the occurrence and development of many cancer types [5], including EC [6]. Development of low toxicity and efficient chemotherapeutics for EC prevention using natural polyphenols are thus urgently required.

Tea is a popular beverage containing high levels of polyphenols, among which green tea is a popular one, particularly in China and Japan. It is made from the leaves of the plant Camellia sinensis. Tea leaves are rich in polyphenolic catechins, with $58.0-183.9 \mathrm{mg} / \mathrm{g}$ by dry weight [7]. More than ten kinds of catechins 
have been detected in different types of processed tea, among which (-)-epigallocatechin-3-gallate (EGCG) is the most abundant, accounting for more than $40 \%$ of total catechins in fresh tea leaves [8]. In recent years, EGCG has attracted extensive research interest because of its health benefits including anti-inflammation [9], antiviral infection [10], anti-amyloidosis [11], anti-cardiovascular disease [12] and anti-tumorigenesis activity [13]. Although there have been several review papers regarding the association of EGCG or green tea with cancer risk, including breast cancer [14], cervical cancer [15] and bladder cancer [16] through affecting a number of signaling pathways [17-19], only one review paper focusing on the effects of tea on EC prevention was published in 2011 [20] based on our literature search of the Embase, PubMed/Medline and Web of Science databases up to early February, 2019. However, many studies have documented the preventive effects of tea or EGCG on EC since 2012 [21-23], and the underlying molecular mechanisms of EGCG on EC remain to be elucidated. Reviewing the recent advances in this topic will be help us to further understanding the relationship between tea drinking and EC risk.

In this review, epidemiologic investigations, studies using cell and animal models regarding to molecular and signaling pathways as well as pharmaceutical synergistic effects associated with green tea or EGCG on EC were summarized. The controversial results as well as directions for further research are also discussed. We expect it will facilitate to develop natural products including tea extracts for EC prevention and treatment.

\section{Literature Search Strategy}

Published literatures regarding to tea or EGCG on EC were searched in the Embase, PubMed/ Medline and Web of Science databases up to Dec 13th, 2018. The search terms used were: (1) "tea" or "green tea" "EGCG" or "polyphenols" or "catechins"; (2) "esophageal carcinoma "or "esophageal cancer "or "esophageal neoplasms"; (3) these searched keywords were combined using "and" without restrictions. We retrieved all the searched papers and removed the duplicate references using Endnote. Then, we read the titles and abstracts of the remaining papers to exclude those which were not related to the research topic. When we could not decide whether a paper should be included or not based on the title and abstract, we read the full text of the article. The searched papers were screened according to the inclusion and exclusion criteria listed in Table 1. The screened papers were then classified into epidemiological studies, animal and cell studies, clinical trials and inconsistent results, which will be cited in the corresponding subtitles. For the epidemiological studies, each was critically appraised by a quality scale, namely, the Newcastle-Ottawa Scale (NOS) [24], which consists of three variables of quality: Selection (4 points), comparability ( 2 points), and outcome (3 points), for a total possible score of 9-points (9 representing the highest quality).

Table 1. Inclusion and exclusion criteria for literature search.

\begin{tabular}{cll}
\hline Search Strategy & \multicolumn{1}{c}{ Details } \\
\hline & $(1) \quad$ The studies were performed on humans, animals, cells. \\
(2) $\quad$ It focuses on the relationship of tea or polyphenol, or EGCG, catechins on EC. However, if one literature \\
was not related with tea and EC but it is necessary for background information, we also cited it in \\
the paper.
\end{tabular}


The studies to be included in Table 2 should meet the following criteria: (1) It was a case-control or cohort study. (2) It tested the association between EC risk and tea drinking; the odds ratios (ORs) or adjusted OR values and relevant corresponding 95\% confidence intervals (CIs) were reported. If the OR value is not available, $p$ value was also accepted. (3) The study was about tea individually or tea was definitely included in the study. (4) It was published in English after 2011. (5) The NOS score $\geq 5$. However, the other literatures regarding to the epidemiological studies may be cited in the other part of the paper for background information.

\section{Epidemiological Evidence}

Earlier researchers had declared that drinking green tea could suppress esophageal carcinogenesis (Table 2). Early in 1994, a population based case-control study launched in China had found that drinking green tea had a possible inhibitory effect on EC [25]. The relationship between tea drinking and decreased EC risk was also confirmed by several case-control studies [26,27], prospective cohort studies [28,29], and meta-analyses [30-32]. It was also shown that women were especially susceptible to the protective effect [25,31-33].

However, in epidemiological studies, the impact of lifestyle, differences of hereditary and other confounding factors can lower the confidence level of cancer preventive effect. Daily drinking tea $\geq 3$ cups could increase the ESCC incidence rate [34]. In addition, inconsistent results were observed when tea was consumed at different temperatures [33]. It was reported that the EC risk increased because of the mucosal damage caused by large amounts of sipping, rapid eating and consumption of high temperature food $[35,36]$. In general, drinking a relatively high quantity of tea at low-temperature had a significantly preventive effect against $\mathrm{EC}$, but the risk increased greatly if green tea was consumed at higher temperatures $\left(70-79{ }^{\circ} \mathrm{C}\right), \mathrm{OR}=2.21,95 \% \mathrm{CI}(1.57-5.53)$; above $80{ }^{\circ} \mathrm{C}$, $\mathrm{OR}=4.74,95 \% \mathrm{CI}$ (2.6-10.51) [33].

Another two strong interfering factors are cigarette smoking and alcohol drinking, which may hinder the suppressive effect of tea drinking on EC risk. Gao et al. carried out a case-control study in China and reported that the prevention effect was only found in persons who didn't smoke, among which most were females [25]. Wu et al. also found a significant negative correlation between drinking green tea and the EC risk among the persons who never smoke or drank no alcohol [37]. After adjusting for confounding factors, the preventive effect of drinking green tea on upper digestive tract cancer was obvious [38].

The preventive efficacy of drinking green tea against EC may be neutralized by the strong side effects of alcohol drinking, smoking, or drinking high temperature beverages. Although a majority of data obtained from epidemiological studies and meta-analyses suggested that EGCG could play a positive role in cancer chemoprevention [20], there was also inconsistent evidence of tea drinking on EC. More epidemiological and clinical studies in consideration of confounding factors are needed to prove the anti-cancer efficacy of green tea consumption, for example, the tea infusion temperature when consumed, the amount and frequency of tea drinking, the effective treatment course, and so on. Table 2 lists the epidemiological studies on the association between tea intake and the risk of EC.

\section{Animal and Cell Studies}

Many studies on cell lines and animal models showed the inhibitory effects of tea EGCG on EC tumorigenesis (Table 3). Potential cancer preventive effects of tea polyphenols or EGCG on EC includes its anti-proliferation, inducing cancer cell apoptosis, inhibiting DNA methylation and angiogenesis, anti-metastasis and relieving oxidant stress. EGCG was observed to regulate multiple signaling pathways related to carcinogenesis. A synergistic effect between green tea components and other clinic treatment methods was also observed. Anticancer effects of green tea and its bioactive constituents on EC in in vitro and in vivo studies are listed in Table 3. 
Table 2. Epidemiological studies of green tea drinking on EC risk.

\begin{tabular}{|c|c|c|c|c|}
\hline $\begin{array}{l}\text { Author } \\
\text { [Reference] } \\
\text { Location } \\
\text { Year }\end{array}$ & $\begin{array}{c}\text { Study Type } \\
\text { Number of } \\
\text { Subjects/Participants }\end{array}$ & $\begin{array}{l}\text { Green Tea Drinking: } \\
\text { Frequency or Amount }\end{array}$ & Risk Estimate of RR $(95 \%$ CI) & Comments \\
\hline $\begin{array}{l}\text { Zheng et al. } \\
\text { [32] } \\
2012\end{array}$ & $\begin{array}{c}\text { Meta-analysis } \\
8 \text { case control } \\
2 \text { cohort studies } \\
33,731 \text { participants } \\
3557 \text { cases }\end{array}$ & $\begin{array}{c}\text { Males and Females } \\
\text { Non-tea drinker } \\
\text { Tea drinker } \\
\text { Males } \\
\text { Non-tea drinker } \\
\text { Tea drinker } \\
\text { Females } \\
\text { Non-tea drinker } \\
\text { Tea drinker }\end{array}$ & $\begin{array}{c}1.00 \\
0.86(0.7-1.03) \\
1.00 \\
1.04(0.49-1.59) \\
1.00 \\
0.43(0.21-0.66)\end{array}$ & $\begin{array}{l}\text { No significant association between green tea consumption } \\
\text { and EC risk, but an evidence of protective effect was } \\
\text { observed among female. }\end{array}$ \\
\hline $\begin{array}{l}\text { Nechuta et al. } \\
\text { [28] } \\
\text { China } \\
2012\end{array}$ & $\begin{array}{l}\text { Prospective cohort study } \\
69,310 \\
\text { participants }\end{array}$ & $\begin{array}{c}\text { Non-tea drinker } \\
\text { Tea drinker: } \\
\text { Amount } \\
<100 \mathrm{~g} / \mathrm{month} \\
100-150 \mathrm{~g} / \mathrm{month} \\
\geq 150 \mathrm{~g} / \text { month } \\
\text { Non-tea drinker } \\
\text { Tea drinker: } \\
\text { Duration } \\
<10 \text { years } \\
10-19 \text { years } \\
\geq 20 \text { years } \\
\text { Overall } \\
\text { Non-tea drinker } \\
\text { Green tea drinker }\end{array}$ & $\begin{array}{c}1.00 \\
\\
0.87(0.55-1.37) \\
0.74(0.47-1.17) \\
0.76(0.48-1.19) \\
1.00 \\
\\
\\
0.85(0.55-1.32) \\
0.77(0.46-1.28) \\
0.74(0.49,1.14) \\
1.00 \\
0.77(0.57-1.03)\end{array}$ & $\begin{array}{l}\text { Adjusted for age, marital status, education, occupation, } \\
\text { BMI, exercise, fruit and vegetable intake, meat intake, } \\
\text { diabetes, and family history of digestive system cancer. }\end{array}$ \\
\hline $\begin{array}{l}\text { Zheng et al. } \\
\text { [30] } \\
2013\end{array}$ & $\begin{array}{c}\text { Meta-analysis } \\
14 \text { case control } \\
2 \text { cohort studies } \\
487,894 \text { controls } \\
7376 \text { cases } \\
8,874,734 \text { participants }\end{array}$ & $\begin{array}{c}\text { Overall } \\
\text { Non-tea drinker } \\
\text { Green tea drinker } \\
\text { China } \\
\text { Non-tea drinker } \\
\text { Green tea drinker }\end{array}$ & $\begin{array}{c}1.00 \\
0.77(0.57-1.04) \\
1.00 \\
0.64(0.44-0.95)\end{array}$ & $\begin{array}{l}\text { Green tea consumption was slightly inversely associated } \\
\text { with EC risk, and it was more evident in Chinese } \\
\text { population. No protective effect was found for black tea } \\
\text { consumption. }\end{array}$ \\
\hline
\end{tabular}


Table 2. Cont

\begin{tabular}{|c|c|c|c|c|}
\hline $\begin{array}{l}\text { Author } \\
\text { [Reference] } \\
\text { Location } \\
\text { Year }\end{array}$ & $\begin{array}{c}\text { Study Type } \\
\text { Number of } \\
\text { Subjects/Participants }\end{array}$ & $\begin{array}{l}\text { Green Tea Drinking: } \\
\text { Frequency or Amount }\end{array}$ & Risk Estimate of RR $(95 \%$ CI) & Comments \\
\hline $\begin{array}{l}\text { Sang et al. } \\
\quad[31] \\
2013\end{array}$ & $\begin{array}{l}\text { Meta-analysis } \\
10 \text { case control } \\
2 \text { cohort studies } \\
487,894 \text { controls } \\
\quad 3821 \text { cases }\end{array}$ & $\begin{array}{l}\text { Males and Females } \\
\text { Non-tea drinker } \\
\text { Tea drinker } \\
\text { Moderate Drinker } \\
\text { Little-drinker } \\
\text { Females } \\
\text { Non-tea drinker } \\
\text { Tea drinker }\end{array}$ & $\begin{array}{c}1.00 \\
1.14(0.97-1.35) \\
0.94(0.77-0.13) \\
0.97(0.77-1.22) \\
\\
1.00 \\
0.46(0.29-0.73) \\
\end{array}$ & $\begin{array}{l}\text { No significant association between green tea consumption } \\
\text { and risk of EC. However, subgroup analysis showed a } \\
\text { significant reduction ( } 54 \% \text { ) in risk of EC in women with the } \\
\text { highest green tea consumption compared with } \\
\text { no/occasional drinkers. }\end{array}$ \\
\hline $\begin{array}{l}\text { Oze et al. } \\
\text { [39] } \\
\text { Japan } \\
2014\end{array}$ & $\begin{array}{l}\text { Hospital based case control } \\
\text { study } \\
961 / 2883\end{array}$ & $\begin{array}{c}\text { Frequency } \\
\text { Less than } 1 \text { cup/day } \\
1 \text { cup/day } \\
2 \text { cups/day } \\
\geq 3 \text { cups/day }\end{array}$ & $\begin{array}{c}1.00 \\
1.20(0.82-1.77) \\
1.00(0.65-1.65) \\
1.31(0.95-1.81) \\
\end{array}$ & $\begin{array}{l}\text { Models included age, sex, coffee and green tea intake, } \\
\text { cumulative smoking, alcohol consumption, fruit and } \\
\text { vegetable intake, body mass index, occupation and } \\
\text { frequency of rice intake. }\end{array}$ \\
\hline $\begin{array}{c}\text { Zamora-Ros et al. } \\
{[40]} \\
9 \text { European } \\
\text { countries } \\
2014 \\
\end{array}$ & $\begin{array}{l}\text { Prospective cohort study } \\
442,143 \text { participants }\end{array}$ & $\begin{array}{c}\text { Non-tea drinker } \\
\text { Green tea drinker } \\
\text { Amount } \\
<178.6 \mathrm{mg} / \mathrm{d} \\
\geq 178.6 \mathrm{mg} / \mathrm{d} \\
\end{array}$ & $\begin{array}{c}1.00 \\
0.85(0.60-1.20) \\
0.74(0.51-1.08) \\
\end{array}$ & $\begin{array}{l}\text { Adjusted for center, sex, age, educational level, smoking } \\
\text { status and intensity, physical activity, energy intake, daily } \\
\text { consumption of fruit, vegetables, red and processed meat } \\
\text { and coffee and tea mutually. }\end{array}$ \\
\hline $\begin{array}{l}\text { Das et al. } \\
\text { [34] } \\
\text { India } \\
2015\end{array}$ & $\begin{array}{l}\text { Hospital based } \\
\text { case control study } \\
39 / 41\end{array}$ & $\begin{array}{c}\text { Tea drinker } \\
\text { cups/day } \\
2 \\
3 \\
4 \\
\end{array}$ & $p=0.0003$ & $\begin{array}{l}\text { Drinking tea } \geq 3 \text { cups/day, the occurrence rate of ESCC } \\
\text { increased. }\end{array}$ \\
\hline $\begin{array}{c}\text { Tai et al. } \\
\quad[41] \\
\text { China } 2017\end{array}$ & $\begin{array}{c}\text { Population-based case-control } \\
\text { study } \\
167 / 167 \\
\end{array}$ & $\begin{array}{l}\text { Tea temperature: } \\
\text { Low or mild }\left(<60^{\circ} \mathrm{C}\right) \\
\operatorname{High}\left(\geq 60^{\circ} \mathrm{C}\right)\end{array}$ & $\begin{array}{c}1.0 \\
2.23(1.45-2.90) \\
\end{array}$ & $\begin{array}{l}\text { Age, sex, education level, body mass index, smoking status, } \\
\text { alcohol drinking, family history of cancer in first degree } \\
\text { relatives, and daily intakes of vegetables and fruits }\end{array}$ \\
\hline $\begin{array}{l}\text { Yang et al. } \\
\text { [42] } \\
\text { China } 2018\end{array}$ & $\begin{array}{c}\text { Population based case control } \\
\text { study } \\
1355 / 1962\end{array}$ & $\begin{array}{l}\text { Never tea drinking } \\
\text { Hot tea drinking }\end{array}$ & $\begin{array}{c}1.00 \\
2.15(1.52-3.05)\end{array}$ & $\begin{array}{l}\text { Adjusted for age, marital status, education, occupation, } \\
\text { family wealth score, body mass index } 10 \text { years ago, sum of } \\
\text { missing and filled teeth, number of tooth brushing per day, } \\
\text { smoking pack-years, alcohol consumption intensity and } \\
\text { family history of EC among first-degree relatives. }\end{array}$ \\
\hline
\end{tabular}


Table 2. Cont.

\begin{tabular}{|c|c|c|c|c|}
\hline $\begin{array}{c}\text { Author } \\
\text { [Reference] } \\
\text { Location } \\
\text { Year }\end{array}$ & $\begin{array}{c}\text { Study Type } \\
\text { Number of } \\
\text { Subjects/Participants }\end{array}$ & $\begin{array}{l}\text { Green Tea Drinking: } \\
\text { Frequency or Amount }\end{array}$ & Risk Estimate of RR $(95 \%$ CI) & Comments \\
\hline $\begin{array}{l}\text { Yu et al. } \\
\text { [43] } \\
\text { China } \\
2018\end{array}$ & $\begin{array}{c}\text { Population based cohort study } \\
456,155 \text { participants }\end{array}$ & $\begin{array}{c}\text { Frequency* } \\
\text { Less Than Weekly } \\
\text { Weekly } \\
\text { Daily } \\
\text { Warm } \\
\text { Hot } \\
\text { Burning hot } \\
\text { Frequency ** } \\
\text { Less Than Weekly } \\
\text { Weekly } \\
\text { Daily } \\
\text { Warm } \\
\text { Hot } \\
\text { Burning hot }\end{array}$ & $\begin{array}{c}1.00 \\
0.82(0.57-1.18) \\
\\
0.92(0.66-1.30) \\
1.23(0.96-1.59) \\
1.36(1.00-1.86) \\
\\
1.90(1.57-2.31) \\
2.60(1.79-3.76) \\
3.74(2.86-4.90) \\
3.84(3.06-4.83) \\
5.00(3.64-6.88)\end{array}$ & $\begin{array}{l}\text { Adjusted for age, sex, education, marital status, household } \\
\text { income, physical activity, intake of red meat, fresh fruits and } \\
\text { vegetables and preserved vegetables, body mass index, } \\
\text { family history of cancer, and tobacco smoking. } \\
\text { *: Participants who consumed pure alcohol }<15 \mathrm{~g} / \text { day or } \\
\text { didn't drink alcohol everyday } \\
*: \text { Participants who consumed pure alcohol }>15 \mathrm{~g} / \text { day } \\
\text { All of the data was calculated with participants who } \\
\text { consumed tea less than weekly and consumed }<15 \mathrm{~g} / \mathrm{d} \text { of } \\
\text { pure alcohol as the reference category. }\end{array}$ \\
\hline
\end{tabular}

Table 3. Anticancer effects of green tea and its bioactive constituents on EC in in vitro and in vivo studies.

\begin{tabular}{|c|c|c|c|c|c|}
\hline $\begin{array}{l}\text { Author/ } \\
\text { Reference }\end{array}$ & $\begin{array}{l}\text { Compound/ } \\
\text { Doses }\end{array}$ & Cell Line & Animal Model & & Observed Effects \\
\hline $\begin{array}{l}\text { Ye et al. } \\
{[17]}\end{array}$ & $\begin{array}{c}\text { EGCG } \\
20-40 \mu \mathrm{M}\end{array}$ & TE-8 SKGT-4 & NA & $\begin{array}{l}\downarrow \\
\uparrow \\
\end{array}$ & Cell proliferation, Invasion, pERK1/2, c-Jun, COX-2 Caspase-3 \\
\hline $\begin{array}{l}\text { Ye et al. } \\
\text { [17] }\end{array}$ & $\begin{array}{c}\text { EGCG } \\
50 \mu \mathrm{g} / \mathrm{kg} / \text { day }\end{array}$ & NA & Nude mouse xenograft & $\downarrow$ & Tumor growth, Ki67, pERK1/2, COX-2 \\
\hline $\begin{array}{l}\text { Hou et al. } \\
\text { [19] }\end{array}$ & $\begin{array}{c}\text { EGCG } \\
5-50 \mu \mathrm{M}\end{array}$ & KYSE150 OE-19 & NA & $\downarrow$ & $\begin{array}{l}\text { EGFR, pEGFR, HER-2/neu, pHER-2/neu, PDGFR } \beta \text { and colony } \\
\text { formation }\end{array}$ \\
\hline $\begin{array}{l}\text { Liu et al. } \\
\text { [22] }\end{array}$ & $\begin{array}{c}\text { EGCG } \\
0-400 \mu \mathrm{M}\end{array}$ & Eca-109 Te-1 & NA & $\begin{array}{l}\downarrow \\
\uparrow \\
\uparrow\end{array}$ & $\begin{array}{c}\text { Proliferation, Cell cycle, VEGF } \\
\text { Apoptosis, ROS, cleaved caspase-3 }\end{array}$ \\
\hline $\begin{array}{l}\text { Liu et al. } \\
\text { [22] }\end{array}$ & $\begin{array}{c}\text { EGCG } \\
10 \mathrm{mg} / \mathrm{kg} / \text { day }\end{array}$ & NA & Nude mouse xenograft & $\begin{array}{l}\downarrow \\
\uparrow\end{array}$ & VEGF, Tumor growth Cleaved-caspase- 3 \\
\hline
\end{tabular}


Table 3. Cont

\begin{tabular}{|c|c|c|c|c|c|}
\hline $\begin{array}{l}\text { Author/ } \\
\text { Reference }\end{array}$ & $\begin{array}{l}\text { Compound/ } \\
\text { Doses }\end{array}$ & Cell Line & Animal Model & & Observed Effects \\
\hline $\begin{array}{l}\text { Gao et al. } \\
\text { [23] }\end{array}$ & $\begin{array}{l}\text { EGCG } \\
50 \mu \mathrm{M}\end{array}$ & Eca-109 & NA & $\uparrow$ & Apoptosis, Caspase-3, Caspase-9, JNK, P38 \\
\hline $\begin{array}{l}\text { Meng et al. } \\
\text { [44] }\end{array}$ & $\begin{array}{c}\text { EGCG } \\
0-200 \mathrm{mg} / \mathrm{L}\end{array}$ & Eca-109 & NA & $\begin{array}{l}\downarrow \\
\uparrow\end{array}$ & Cell proliferation Apoptosis, p16 gene demethylation \\
\hline $\begin{array}{l}\text { Liu et al. } \\
\text { [45] }\end{array}$ & $\begin{array}{c}\text { EGCG } \\
0-400 \mathrm{mg} / \mathrm{L}\end{array}$ & Ec-9706 Eca-109 & NA & $\begin{array}{l}\downarrow \\
\uparrow\end{array}$ & $\begin{array}{l}\text { Cell proliferation, telomerase activity, mitochondrial membrane } \\
\text { potential } \\
\text { Apoptosis, Caspase-3 }\end{array}$ \\
\hline $\begin{array}{l}\text { Liu et al. } \\
\text { [46] }\end{array}$ & $\begin{array}{c}\text { EGCG } \\
0-400 \mathrm{mg} / \mathrm{L}\end{array}$ & Ec-9706 Eca-109 & NA & $\begin{array}{l}\downarrow \\
\uparrow\end{array}$ & $\begin{array}{l}\text { Cell proliferation, Bcl-2 } \\
\text { Apoptosis, Bax, Caspase-3 }\end{array}$ \\
\hline $\begin{array}{l}\text { Li et al. } \\
{[47]}\end{array}$ & EGCG4-10 mg/kg & NA & NMBA-induced F344 rat & $\downarrow$ & Cyclin D1, COX-2, PGE-2, tumor growth, EC incidence rate \\
\hline $\begin{array}{l}\text { Song et al. } \\
{[48]}\end{array}$ & $\begin{array}{l}\text { Polyphenon E } \\
20-40 \mu \mathrm{g} / \mathrm{mL}\end{array}$ & $\begin{array}{l}\text { SEG-1 } \\
\text { BIC-1 } \\
\text { SKGT-4 } \\
\text { BE-3 }\end{array}$ & NA & $\begin{array}{l}\downarrow \\
\uparrow\end{array}$ & $\begin{array}{l}\text { Cell proliferation, Cyclin D1, } \\
\text { Apoptosis, dephosphorylation of } \mathrm{Rb}\end{array}$ \\
\hline $\begin{array}{l}\text { Chen et al. } \\
\text { [49] }\end{array}$ & $\begin{array}{l}\text { Green tea } \\
\quad 1-5 \mathrm{~g}\end{array}$ & NA & NMBA-induced Wistar rat & $\downarrow$ & $\begin{array}{c}\text { Tumor incidence, tumor growth, DNA methylation, urinary } \\
\text { N-nitrosoproline (NPRO) excretion, incidences of general lesions and } \\
\text { precancerous lesions }\end{array}$ \\
\hline $\begin{array}{l}\text { Fang et al. } \\
{[50]}\end{array}$ & $\begin{array}{c}\text { EGCG } \\
5-50 \mu \mathrm{M}\end{array}$ & KYSE 510 & NA & $\begin{array}{l}\downarrow \\
\uparrow\end{array}$ & $\begin{array}{c}\text { DNMT, cell growth } \\
\text { Reversal of hypermethylation and reactivation of RAR } \beta, \text { MGMT, } \\
\text { p16 }{ }^{\text {INK4a }} \text { and hMLH1 }\end{array}$ \\
\hline $\begin{array}{l}\text { Morse et al. } \\
\text { [51] }\end{array}$ & $\begin{array}{c}\text { EGCG } \\
360 \text { or } 1200 \text { ppm } \\
\end{array}$ & NA & NMBA-induced F344 rat & $\downarrow$ & Tumor incidence, tumor multiplicity \\
\hline $\begin{array}{l}\text { Wang et al. } \\
{[52]}\end{array}$ & $\begin{array}{c}0.6 \% \text { or } 0.9 \% \text { green tea } \\
\text { extract }\end{array}$ & NA & $\begin{array}{l}\text { NMBA- induced rat } \\
\text { model }\end{array}$ & $\downarrow$ & Tumor incidence, tumor multiplicity, tumor growth \\
\hline
\end{tabular}

Note: NA, No available; $\downarrow$ Inhibit; $\uparrow$ Promote. Abbreviation: pERK, phosphorylated extracellular regulated protein kinases; COX-2, Cyclooxygenase-2; EGFR, epidermal growth factor receptor; pEGFR, phosphorylated epidermal growth factor receptor; HER-2, human epidermal growth factor receptor-2; PDGFR $\beta$, platelet-derived growth factor receptor $\beta$; VEGF, vascular endothelial growth factor; ROS, reactive oxygen species; JNK, c-Jun N-terminal kinase; BCL-2, B-cell lymphoma-2; Prostaglandin E2, PGE-2; MGMT, O6-methylguanine methyltransferase; hMLH1, human mutL homologue 1; RAR $\beta$, retinoic acid receptor; NMBA, N-Nitrosomethylbenzylamine; DNMT, DNA methyltransferases. 


\subsection{Anti-Proliferation and Inducing Esophageal Cancer Cell Apoptosis}

The proliferation and metastasis of EC cells are important factors leading to tumor growth. One of the major characteristics in advanced EC patients is the infinite proliferation of cancer cells. The benefit of inhibiting proliferation of EC cells, first and foremost, is stabilizing the symptoms of the patients and prolonging more treatment time for the doctor.

EGCG could inhibit cancer cell proliferation and induce EC apoptosis [44-47,53]. It was reported that EGCG inhibited the proliferation and induced EC cells apoptosis (Ec9706 and Eca109) in a time- and dose-dependent manners by modulating the expression of telomerase activity, caspase- 3 protein and membrane potential of mitochondrial $[45,46]$ or through p16 gene demethylation [44]. EGCG treatment inhibited the expression levels of anti-apoptotic protein involving Bcl-2 in the NF- $\mathrm{kB}$ pathways, and increased the bax and caspase-3, resulting in the cell cycle arrest in G1 phase [46]. It also induced EC cell lines Te-1 and Eca-109 apoptosis [22].

Green tea extracts rich in EGCG inhibited the proliferation of human Barrett's esophagus cell BE3 and EAC cells (SKGT-4, SEG-1 and BIC-1), arrested the cell cycle in G0-G1 phase through inhibiting cyclin D1 expression, promoting its degradation or dephosphorylation of $\mathrm{Rb}$ [48].

\subsection{Anti-Metastasis}

Adhesion, migration, and invasion are the three crucial steps for EC cells metastasis. EGCG treatment $(40 \mu \mathrm{M})$ or in combination with curcumin, lovastatin can effectively inhibit the invasion of EC cell lines SKGT-4 and TE-8 [17].

The anti-metastasis effects of EGCG are related to its regulation of carcinogenesis factors. VEGF, a key regulating factor for angiogenesis, plays a pivotal role in tumor cell metastasis. Treatment with EGCG down-regulated the expression levels of VEGF in ESCC cell lines (Eca-109 and Te-1), resulting in the inhibition of cell migration [22]. Matrix metalloproteinases (MMP) are a family of proteolytic enzymes which are involved in a variety of physiological and pathological processes [54]. Their main physiological role is to degrade extracellular matrix (ECM) and most protein components in ECM can be degraded by MMPs, which is very important in cancer cell behavior of invasion and metastasis. Treatment to oral squamous cancer cells (OEC-M1) with $>5 \mu \mathrm{M}$ EGCG significantly inhibited the expression of MMP-13. The mRNA of MMP-13 also showed higher expression in ESCC [55], so it is very likely that EGCG could suppress the metastasis of ESCC cell through inhibiting the expression of MMP-13. EGCG also can suppress tumor metastasis through the regulation of related signaling pathways, such as the EGFR signaling pathway [56].

\subsection{Inhibiting Tumor Angiogenesis}

Polyphenols were reported to regulate the functions of various cancer-related signaling molecules. The inhibitory efficacy of EGCG against angiogenesis has been reported in several studies. VEGF is a highly specific growth factor that could increase vascular permeability, extracellular matrix degeneration, proliferation and migration of vascular endothelial cell, and promote angiogenesis. Treatment with EGCG was shown to decrease VEGF expression in ESCC cell lines (Te-1 and Eca-109) and suppress angiogenesis in the patient-derived tumor xenograft (PDX) model of EC. Furthermore, cyclin D1, a key regulator of cyclin-dependent kinase (CDK) and caspase-3, the most important terminal cleavage enzyme in apoptosis, are also regulated by EGCG [22,47].

\subsection{Inhibiting DNA Methylation}

Epigenetic alteration is reversible. More and more studies have been focused on cancer epigenetics alterations in the last few years, including DNA methylation, gene silencing, genomic imprinting and microRNAs [57]. EGCG can suppress the initiation of EC by inhibiting DNA methylation [49]. Actually, DNA hyper-methylation is involved in various key events in cancer progression, for example, regulating the cell cycle, repairing of the DNA damage, and inducing cancer cell apoptosis [58-60]. 
It was reported that DNA methyltransferase (DNMT) could cause methylation of CpG island (the regions of DNA that contain several $\mathrm{CpG}$ sites) and further lead to the condensation of chromosome and transcription inhibition [61,62].

DNA demethylation is an important method of cancer treatment, and studies using DNMT inhibitors have further confirmed its possible efficacy. DNMT inhibitor was used to treat cancer cells and mice. EGCG inhibits DNMT and reactivates methylation-silenced genes in cancer cell lines, and thus inhibiting the cancer cell proliferation, inducing cancer cells apoptosis and reducing the tumor volume compared with the control group [63-65]. Fang et al. found that EGCG could act as an effective DNA methylation inhibitor. Treating with EGCG (5-50 $\mu \mathrm{M}$, for 12-144 h) on human EC cells (KYSE 510) was able to suppress DNMT1 activity, leading to concentration- and time-dependent reversal of hyper-methylation and reactivation of several tumor methylation-silenced genes (p16, RAR $\beta$, hMLH1 and MGMT) [50]. EGCG also have been confirmed to induce ECa109 cell apoptosis and inhibit cell growth through p16 gene demethylation [44].

\subsection{Regulating Cell Signaling Pathway and Interacting with Target Proteins}

Various cancer-related signaling pathways and molecules have been reported to be regulated by EGCG, such as blocking the cell cycle in G0-G1 phase [66,67] and inducing cancer cell apoptosis $[44,46]$, suppressing the activity of ERK1/2 [17] and mitogen activation protein kinases (MAPKs) [23,68,69], EGFR phosphorylation [56], activator protein-1(AP-1) [70], DNMT [50] and cell transformation [71,72]. In particular, 67-kDa laminin receptor (67LR), a master regulator of many signaling pathways, has been identified as a direct target of EGCG, which was able to be bound by EGCG, thus exerting anticancer activity [73].

The MAPKs, including MAPK/ERK, stress activated protein kinases (SAPK)/JNK and p38, can transduce multiple signaling pathways, leading to a wide variety of cellular responses, such as cell proliferation, differentiation, inflammation and apoptosis [74]. Gao et al. have reported that EGCG could induce EC cell line Eca-109 apoptosis through regulating the expression of JNK and P38 [23].

In human ESCC cell lines (TE-8 and SKGT-4) and EC tissue samples from the patients, the COX-2, phosphorylated ERK1/2 and c-Jun were overexpressed. However, their expression was significantly decreased after treatment with EGCG $(40 \mu \mathrm{M})$ [17]. A PDX model test also proved that treatment with EGCG (50 $\mu \mathrm{g} / \mathrm{kg}$ daily) could decrease expression levels of phosphorylated ERK and COX-2, accompanying with inhibition of tumor formation and growth [17].

Telomerase is very active in many kinds of cancer cells, and its activity is essential for survival of malignant cancer cells, helping them to have infinite division potential. Telomerase activity was downregulated in ESCC cell lines Eca109 and Ec9706 treated with EGCG [45].

EGCG also shows a tumor suppression mechanism through inhibiting the phosphorylation of HER-2/neu and EGFR in ESCC cell line KYSE 150, resulting in the suppression of growth factor receptor [19]. There was an animal study showing that administration of EGCG $(4 \mathrm{mg} / \mathrm{kg})$ in $\mathrm{N}$-nitrosomethylbenzylamine (NMBA)- induced EC rats decreased the expression of genes COX-2 and cyclin D1, leading to the reduction of the PGE-2 production [47], indicating that EGCG may exert anti-tumor effects through regulating COX-2 and cyclin D1. Similar results were further confirmed by another NMBA-induced F344 rat model test [75]. These experiments indicated that EGCG may have a preventive effect on EC, and the related mechanism may be through downregulating the inflammatory-related factors, such as COX-2, ERK1/2, and c-Jun. Figure 1 illustrates possible mechanisms of EGCG on EC based on the published literature.

\subsection{Antioxidant and Pro-Oxidation}

In normal cells, EGCG is a natural antioxidant agent, possessing strong scavenging capacity for free radicals including hydroxyl radical, superoxide anion and hydrogen peroxide. One of the prime explanations is that the poly-hydroxyl structure plays an important role [76-78]. Tea polyphenols were found to inhibit the production of ROS like nitrogen dioxide $\left(\mathrm{NO}_{2}\right)$, nitric oxide (NO), 
and peroxynitrite [77]. EGCG, a preponderant constituent of tea polyphenols, could decrease lipid peroxidation and several pro-inflammatory cytokines, and relieve oxidative DNA damage through regulating Nrf2-Keap1 signaling pathway [79,80]. It also increased the generation of some detoxification enzymes, like GST (glutathione $S$-transferase), COX-2, CAT, GPX, and inhibited the accumulation of transcription factors which is redox sensitive in nucleus such as NF-kB, AP-1 in different experimental models [77,81-83]. It was found that green tea catechins have a stronger protective effect against the progression of gastric and esophageal cancers among the participants who are lack of serum carotenes [84].

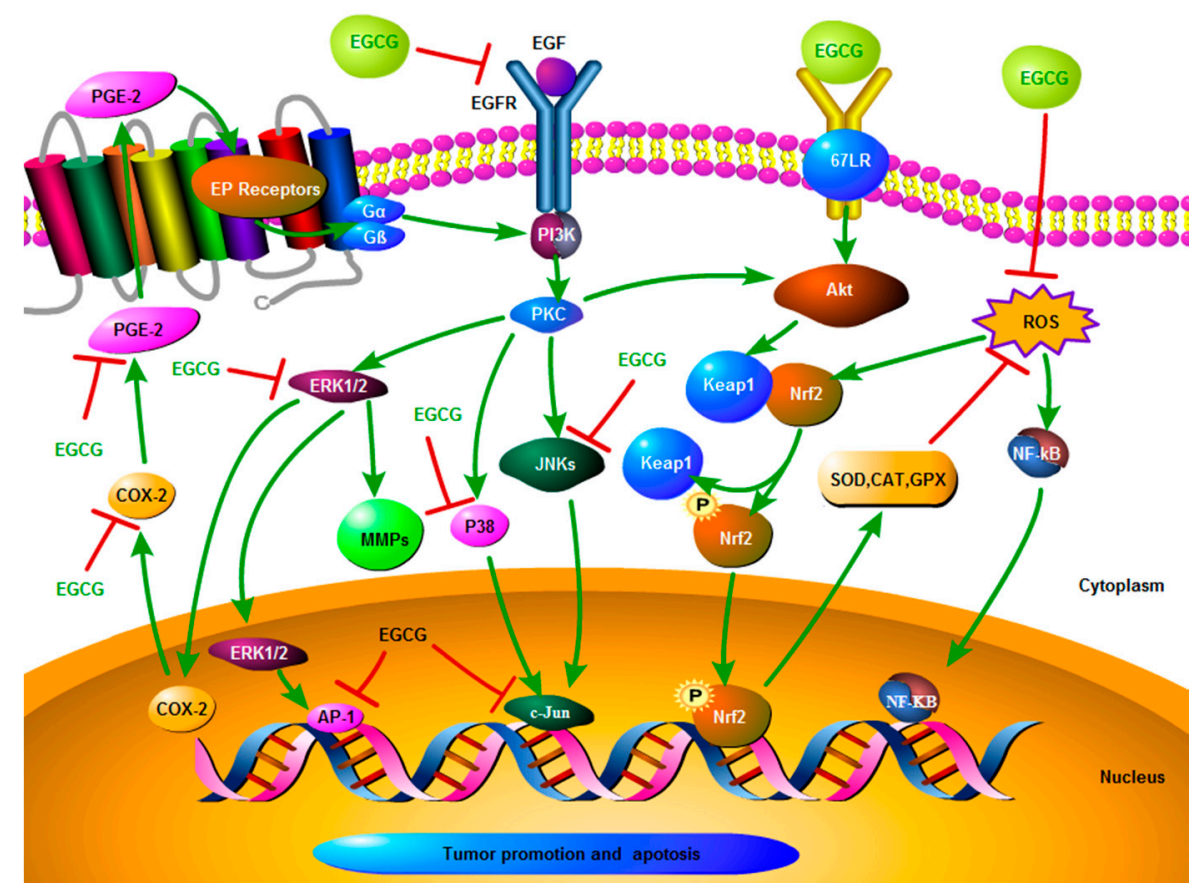

Figure 1. Possible mechanisms of EGCG on EC based on published literatures. Note: A red symbol" T" means "Inhibition"; a green arrow means "Activation". Abbreviation: PKC: protein kinase C; PI3K, phosphatidylinositol 3-kinase; Akt, protein kinase B; SOD, Superoxide dismutase; CAT, catalase; GPX, glutathione peroxidases; EP, E-series of Prostaglandin; $\mathrm{G} \alpha / \beta$, G protein $\alpha / \beta$; Nrf2, nuclear related factor erythroid-derived 2; Keap1, Kelch like ECH associated protein 1; NF-kB, Nuclear factor kB.

Low concentration EGCG itself can be oxidized to produce ROS and exhibit pro-oxidant and apoptosis-inducing properties in cancer cells because they were unstable $[19,85]$. For example, it can induce ROS production in ESCC cell lines (Te-1 and Eca-109) [22]. Pretreatment of ESCC cell line KYSE 150 with EGCG before the addition of EGF led to 32-85\% reduction of phosphorylated EGFR and $80 \%$ decrease in EGFR protein expression. The addition of SOD to the cell culture medium can inhibit or reduce these effects induced by EGCG. EGCG was easy to form dimers or other oxidative products when co-cultured with ESCC cell line KYSE 150. In the culture medium, EGCG was stabilized by SOD, and the ability of EGCG to inhibit cell growth was also enhanced. These studies indicate that the auto-oxidation of EGCG under cell culture conditions may result in the inactivation of EGFR-related signaling pathway [19].

\subsection{Animal Model Tests}

As early as 1992, Chen reported that oral administration of green tea to the rats significantly reduced the esophageal tumors occurrence induced by NMBA [49]. Another experiment confirmed that drinking water containing 1200 ppm EGCG for 14 days before administration of NMBA significantly 
reduced the rates of esophageal tumor formation [51]. The mechanism is considered to suppress the expression of cyclin D1 and COX-2, and induced the production of PGE-2 [47].

In a tumor mouse model transplanted with Eca-109 cell of ESCC, treatment with EGCG significantly reduced the tumor volume through decreasing expression levels of VEGF protein and increasing cleaved-caspase-3 [22]. Another study found the similar inhibitory effects in a PDX nude mouse model through downregulating the expression of COX-2, pERK1/2, c-Jun and upregulating the expression of activated caspase 3 [17]

Wang et al. reported that administration of $0.6 \%$ green tea regularly during or after treatment by NMBA could significantly reduce esophageal tumorigenesis in rats (a reduction of approximately $70 \%$ and $50 \%$, respectively), the possible mechanism may be through inhibition of tumor incidence and multiplicity, the tumor volume of the mice was also significantly reduced by regular drinking $0.9 \%$ green tea [52]. However, $\mathrm{Li}$ et al. reported that drinking beverages at high temperature can lead to increased esophageal carcinoma risk, and thus the anticancer efficacy of EGCG on NMBA induced rat esophageal tumorigenesis may be offset [75].

\subsection{Pharmaceutical Synergistic Effect}

Radiotherapy and chemotherapy are traditionally or frequently used cancer therapy methods, but adverse effects of these treatment methods are hard to bear before the patients have been cured. Therefore, natural extracts with synergistic effect can be used to lower the adverse-effects of traditional cancer treatment methods are urgently needed.

A combination of EGCG, curcumin and lovastatin can significantly enhance the anticancer efficacy compared to using any one of them alone. They inhibited the proliferation and invasion of EC cells (SKGT-4 and TE-8), and reduced the expression of c-Jun, pERK1/2, Ki67, and COX-2, but activated caspase-3 in xenograft tissues [17]. EGCG also inhibited the ABCG2 expression in a multidrug resistance ESCC cell line Eca109. Compared with adriamycin (ADM) treatment alone, the rate of apoptosis of Eca109/ABCG2 cells treated by combination of EGCG with ADM for $24 \mathrm{~h}$ enhanced ADM concentration in the cancer cells, suggesting that EGCG can reverse multi-drug resistance by reducing the expression of $A B C G 2$ and increase the concentration of drug in cancer cells to enhance the anticancer effects [46]. Gao et al. confirmed that vitamin C could significantly enhance the therapeutic properties of EGCG through activating the activity of caspase-3/9, inducing cancer cell apoptosis by regulating MAPK pathways [23]. Table 4 lists the pharmaceutical synergistic effects of EGCG with other treatments on EC.

Table 4. Pharmaceutical synergistic effects of EGCG with other treatments on EC.

\begin{tabular}{|c|c|c|c|c|}
\hline Reference & Ingredient & Drug & Cell Line & Cytotoxic Action \\
\hline $\begin{array}{l}\text { Ye et al. } \\
\text { [17] } \\
2012\end{array}$ & $\begin{array}{c}\text { EGCG } \\
20-40 \mu \mathrm{M} \text { or } 50 \\
\mu \mathrm{g} / \mathrm{kg} / \text { day }\end{array}$ & $\begin{array}{l}\text { Curcumin, } \\
\text { lovastatin, or } \\
\text { curcumin and } \\
\text { lovastatin }\end{array}$ & SKGT-4 TE-8 & $\begin{array}{l}\text { Suppressing tumor cell viability and invasion; } \\
\text { inhibiting xenograft tumor growth in nude } \\
\text { mouse through downregulating the expression } \\
\text { of p-ERK1/2, c-Jun and COX-2; upregulating } \\
\text { caspase } 3 \text { expression. }\end{array}$ \\
\hline $\begin{array}{l}\text { Gao et al. } \\
\text { [19] } \\
2013\end{array}$ & $\begin{array}{l}\text { EGCG } \\
50 \mu \mathrm{M}\end{array}$ & Vitamin C & Eca-109 & $\begin{array}{c}\text { Vitamin C could enhance the therapeutic } \\
\text { properties of EGCG, activate caspase-3/9, } \\
\text { induce apoptosis and regulate MAPK } \\
\text { pathways. }\end{array}$ \\
\hline $\begin{array}{l}\text { Hou et al. } \\
\text { [23] }\end{array}$ & $\begin{array}{c}\text { EGCG } \\
5-50 \mu \mathrm{M}\end{array}$ & SOD & KYSE150 & $\begin{array}{l}\text { EGCG was stabilized by SOD, and the growth } \\
\text { inhibitory effect of EGCG on EC cell was } \\
\text { potentiated by downregulating the activity of } \\
\text { EGFR or HER-2/neu. }\end{array}$ \\
\hline $\begin{array}{l}\text { Liu et al. } \\
\text { [46] } \\
2017\end{array}$ & $\begin{array}{c}\text { EGCG } \\
0-400 \mathrm{mg} / \mathrm{L}\end{array}$ & $\mathrm{ADM}$ & Eca-109 & $\begin{array}{l}\text { EGCG promoted the rate of apoptosis and } \\
\text { reversal of multidrug resistance induced by } \\
\text { ADM through reducing the ABCG2 expression } \\
\text { of Eca109/ABCG } 2 \text { cells. }\end{array}$ \\
\hline
\end{tabular}




\section{Clinical Trials}

Barrett's esophagus (BE) patients have a higher EC risk, and currently there are no available methods for cancer prevention in this population [86]. Therefore, such patients must undergo invasive endoscopy, including multiple biopsies. Joe et al. completed a prospective, phase I, placebo-controlled trial in patients with BE using a formula "Poly E" containing green tea EGCG. It showed that EGCG was significantly accumulated in the esophageal mucosa of the target organ after administration poly E (400 mg or $600 \mathrm{mg}$ ), which was clinically relevant and detectable, indicating that poly $\mathrm{E}$ has a measurable positive protective effect in esophageal tissue [87]. Acute radioactive esophagitis (ARIE) is one of the most frequent adverse effects of chest radiotherapy in the treatment of lung cancer complications, which seriously affects the life quality of patients and the effect of radiotherapy. So far it has been difficult to be overcome quickly. A prospective phase II clinical trial in China confirmed that oral administration of EGCG was an effective therapy method for ARIE, which can significantly reduce the pain of patients and improve the therapeutic effect [88].

One of the major challenges of EGCG for cancer prevention is to discover new biomarkers and use them in clinical practice. Therefore, it is important to identify more targets and biomarkers of tea polyphenols in EC for the implementation of green tea experimental design, and this will greatly help to better understand the mechanism of its activity of cancer prevention.

\section{Discussion}

\subsection{Inconsistent Results}

Although cell and animal studies have shown that tea polyphenols have a positively protective effect on the prevention and treatment of EC, there are also inconsistent results from human epidemiological studies. Many factors related to the consumption of green tea may lead to these inconsistent result, for instance, the type and quantity of tea intake, the temperature of the tea beverage, the low bioavailability of tea polyphenols, and the different etiology of cancer in different regions. For example, a European prospective study showed no significant association between tea intake and risk of EC, EAC and ESCC [40].

In the epidemiological studies, the quantity of tea drinking was mainly investigated, while the temperature of tea infusion when consumed was rarely concerned. Consuming tea at higher temperature might confound the relationship between EC risk and green tea drinking. Yang et al. reported that very daily hot tea drinking significantly increased the risk of ESCC among Chinese men, which is particularly evident among alcohol drinkers [89]. The most recent meta-analysis also showed an approximately 2-fold increased risk for ESCC in association with consumption of hot food or drinks [42]. It has been verified that it was the temperature effect but not tea constituent may pose an EC risk through comparing the margin of exposure of polycyclic aromatic hydrocarbons (PAH) vs. very hot temperatures [90]. Smoking and alcohol drinking might be associated with the inconsistent results. Yu et al. showed that persons who drank hot tea in combination with alcohol and/or smoking had 5-fold times of EC risk [43].

Different kinds of tea have different inhibitory effects on EC. Green tea instead of black tea is generally associated with a reduced risk of EC $[32,39,40]$. The reason may be that the main biological active ingredient possessing anti-cancer property in tea is catechins, especially EGCG, and most of the catechins are oxidized during black tea processing, during which most of tea catechins are oxidized and condensed into theaflavins and thearubigins.

Identifying specific, objective biomarkers for metabolism of EGCG in human body may help the assessment of relationship between tea drinking and EC risk. Rasool et al. found a significant correlation between the ECRG1 genetic polymorphism and ESCC in Kashmiri population [91]. More different population-based studies are needed to prove the function of the biomarker.

Bioavailability of tea catechins during human tea consumption was very low, and the dosage of daily tea consumption was also lower than those used in laboratory studies. These may be partially 
responsible for the inconsistent results. Meng et al. reported that oral administration $2 \mathrm{mg} / \mathrm{kg}$ EGCG, the maximum plasma concentration was only $0.09 \mu \mathrm{M}$, indicating a rather low bioavailability of EGCG [92].

\subsection{Further Study Directions}

The inhibitory effect of EGCG alone on EC is limited. However, combination of EGCG with radiotherapy, chemotherapy, molecular targeted therapy, immunotherapy or other natural compounds has been shown to have a better clinical efficacy in treatment of cancer patients, including EC [93,94]. Green tea has been recognized as an effective sensitizer that can enhance the radiotherapy effect of prostate cancer [95] and breast cancer [96]. However, few researches have been performed on the adjunctive effect of green tea on radiotherapy for EC.

Further study on the synergistic anti-tumor effect of catechins with other bioactive compound and the method for stabilizing catechins in the digestive tract will be helpful to improve the oral bioavailability and anti-cancer effect of catechins. It has been reported that EGCG acetylation can significantly improve the bioavailability in vivo and in vitro of colorectal cancer and EC $[97,98]$.

A meta-analysis reported that there was an increased ESCC risk in the population infected by HPV-16 [99]. EGCG could inhibit the growth and induce cancer cells apoptosis through regulating the expression of HPV oncoproteins [15], so it may be used as an effective dietary agent to prevent infection of HPV by targeting the oncoproteins.

MicroRNA is a class of non-coding, short RNA, which are responsible for regulating the expression of post-transcriptional gene. Several studies have revealed that EGCG had the potential to regulate the expression of microRNA in melanoma [100], colorectal cancer [101] and lung adenocarcinoma [102]. Indeed, there are some dysregulated miRNAs in ESCC [103]. Hence, targeting the microRNAs using tea catechins may be a promising project in EC therapy.

The cancer stem cell (CSC) is a member of cancer cells that have stem cell properties, which plays important roles in tumorigenesis, tumor recurrence, cancer metastasis and chemotherapy resistance. EGCG can target CSCs for cancer prevention and treatment [104]. For example, EGCG treatment significantly inhibited spheroid formation, ALDH activity, and expression of specific genes in human neuroblastoma CSCs, such as Oct 4 and Nanog [105] and the tumor volume in PDX models [106]. Chen et al. discovered that EGCG could suppress the spheroid formation of colorectal CSCs by inhibition of the Wnt pathway [107]. Recently, Kumazoe et al. reported that combination treatment of EGCG with phosphodiesterase 3 inhibitor successfully suppressed CSC properties in pancreatic adenocarcinoma [108] and Chani et al. found that EGCG significantly inhibited mesenchymal stem cell differentiation to adipogenic lineage [109], suggesting that EGCG may intervene in either obesity or metabolic syndrome-associated cancer. Till nowadays, there have been very rare studies on the effect of EGCG on CSCs of EC, therefore, targeting CSCs with EGCG for EC prevention and treatment may be a promising project in future.

P53 is the most common mutation gene in ESCC, and about half of EC patients have P53 gene mutation or overexpression, even in the early stage of cancer [110,111]. It is considered as an important biomarker in the diagnosis and therapy of ESCC [112,113]. P53 was a good predictor for therapy response and survival, and the overall 5-year survival rate of the ESCC patients was significantly higher in the p53-normal group than the p53-alteration group [113,114]. Thus, P53 is a promising target for anticancer drugs. EGCG also could suppress the growth of breast cancer cells and induce apoptosis through regulating P53/Bcl-2 signaling pathway [115]. However, the inhibition mechanism of EGCG for EC needs more research to support the efficacy in the future.

Compared with normal cells, the cancer cells exhibit some different biophysical properties, such as cell stiffness and elasticity, and the cell stiffness has been identified as a new biomarker of the metastatic potential in cancer cells [116]. Recently, Suganuma et al. have made some new discoveries in cancer research by using biophysical tools, such as atomic force microscope (AFM). In their study, they found that after treatment with EGCG, the melanomas and various cancer cells have a significantly lower 
average value of Young's moduli, indicating that EGCG may inhibit cell migration and metastasis through increasing the stiffness of cancer cells [117]. We suggest that more study on the biophysical properties of cancer cells are needed because this will play an important role in early diagnosis and prevention of cancer cell metastasis.

Drinking one cup of green tea (containing about 200 mg EGCG) daily has been shown to have chemo-preventive effects on several kinds of cancer [118]. The proper drinking amount of green tea is advised to have three to five cups per day, which is equivalent to about 600-1000 mg EGCG [119]. Suganuma et al. proposed that drinking over 10 cups of green tea per day (equivalent to $25 \mathrm{~g}$ green tea) can prevent the recurrence of various cancers [117]. Based on the average content of EGCG in dried green tea (about $80 \mathrm{mg} / \mathrm{g}$ ) [120], the results of epidemiological and clinical trials, and in consideration of the extraction rate of the tea catechins, we recommend that daily drinking 5-7 cups of green tea $(15-20 \mathrm{~g})$ at a lower temperature may be a positive method for the prevention of EC. More clinical trials and epidemiological studies considering the drinking amount are needed to support the preventive effects of EGCG on EC. Furthermore, it was reported that tea catechins inhibited influenza viral adsorption and suppressed replication and neuraminidase activity. Tea catechins enhance immunity against viral infection [10], suggesting that the cancer inhibition effect of tea catechins might also be indirectly linked with cancer progression as catechins have good influence on human health.

\section{Conclusions}

In this review, we summarized the advances in the possible antitumor effects of green tea polyphenols or EGCG in EC prevention and treatment. Possible mechanisms of EGCG against EC included inhibition of EC cell proliferation, DNA methylation, angiogenesis, enhancement of apoptosis, anti-metastasis, antioxidant or pro-oxidant, synergistic effect in combination with other treatment methods as well as the modulation of multiple signal transduction and metabolic signaling pathways involved in carcinogenesis.

Some epidemiological studies showed inconsistent results, these inconsistencies can be attributed to differences in temperature of tea solution when drinking, the quantity of green tea intake, and the influence of other factors, such as smoking, alcohol drinking. More studies are needed to identify the precise preventive mechanisms of EGCG on EC. Overall, EGCG shows an inhibitory effect on EC in laboratory studies.

Author Contributions: Literature search, 1. Introduction and Abstract, 2, Literature search strategy, L.-X.W.; 3. Epidemiological Evidence, Y.-L.S. and L.-J.Z.; Table 2, K.-R.W.; 4. Animal and cell studies, Table 3, L.-P.X., J.-L.L. and J.-H.Y.; Figure 1 and Table 4, Z.-Y.C.; Project design, 5.Clinical trials, 6. Discussion and 7. Conclusions, Y.-R.L. and X.-Q.Z.

Funding: This research was financially supported by grants from the Science Technology Department of Zhejiang Province (Project No. 2016C02053-5) and the Science Technology Bureau of Ningbo City (Project No. 2017C10001).

Acknowledgments: The authors acknowledge the Science Technology Department of Zhejiang Province and the Science Technology Bureau of Ningbo City for financial support to this work.

Conflicts of Interest: The authors declare no conflict of interest.

\section{References}

1. Bray, F.; Ferlay, J.; Soerjomataram, I.; Siegel, R.L.; Torre, L.A.; Jemal, A. Global cancer statistics 2018: GLOBOCAN estimates of incidence and mortality worldwide for 36 cancers in 185 countries. CA Cancer J. Clin. 2018, 68, 394-424. [CrossRef] [PubMed]

2. Gao, Q.Y.; Fang, J.Y. Early esophageal cancer screening in China. Best Pract. Res. Clin. Gastroenterol. 2015, 29, 885-893. [CrossRef] [PubMed]

3. Pennathur, A.; Gibson, M.K.; Jobe, B.A.; Luketich, J.D. Oesophageal carcinoma. Lancet 2013, 381, 400-412. [CrossRef]

4. Enzinger, P.C.; Mayer, R.J. Esophageal cancer. N. Engl. J. Med. 2003, 349, 2241-2252. [CrossRef] [PubMed] 
5. Zhou, Y.; Zheng, J.; Li, Y.; Xu, D.P.; Li, S.; Chen, Y.M.; Li, H.B. Natural Polyphenols for Prevention and Treatment of Cancer. Nutrients 2016, 8, 515. [CrossRef] [PubMed]

6. Higdon, J.V.; Frei, B. Tea catechins and polyphenols: Health effects, metabolism, and antioxidant functions. Crit. Rev. Food Sci. Nutr. 2003, 43, 89-143. [CrossRef]

7. $\quad$ Liang, Y.R.; Ye, Q.; Jin, J.; Liang, H.; Lu, J.L.; Du, Y.Y.; Dong, J.J. Chemical and instrumental assessment of green tea sensory preference. Int. J. Food Prop. 2008, 11, 258-272. [CrossRef]

8. Dong, J.J.; Ye, J.H.; Lu, J.L.; Zheng, X.Q.; Liang, Y.R. Isolation of antioxidant catechins from green tea and its decaffeination. Food Bioprod. Process. 2011, 89, 62-66. [CrossRef]

9. Oliviero, F.; Scanu, A.; Zamudio-Cuevas, Y.; Punzi, L.; Spinella, P. Anti-inflammatory effects of polyphenols in arthritis. J. Sci. Food Agric. 2018, 98, 1653-1659. [CrossRef]

10. Furushima, D.; Ide, K.; Yamada, H. Effect of Tea Catechins on Influenza Infection and the Common Cold with a Focus on Epidemiological/Clinical Studies. Molecules 2018, 23, 1795. [CrossRef]

11. Polito, C.; Cai, Z.Y.; Shi, Y.L.; Li, X.M.; Yang, R.; Shi, M.; Li, Q.S.; Ma, S.C.; Xiang, L.P.; Wang, K.R.; et al. Association of Tea Consumption with Risk of Alzheimer's Disease and Anti-Beta-Amyloid Effects of Tea. Nutrients 2018, 10, 655. [CrossRef] [PubMed]

12. Eng, Q.Y.; Thanikachalam, P.V.; Ramamurthy, S. Molecular understanding of Epigallocatechin gallate (EGCG) in cardiovascular and metabolic diseases. J. Ethnopharmacol. 2018, 210, 296-310. [CrossRef] [PubMed]

13. Gan, R.Y.; Li, H.B.; Sui, Z.Q.; Corke, H. Absorption, metabolism, anti-cancer effect and molecular targets of epigallocatechin gallate (EGCG): An updated review. Crit. Rev. Food Sci. Nutr. 2018, 58, 924-941. [CrossRef] [PubMed]

14. Xiang, L.P.; Wang, A.; Ye, J.H.; Zheng, X.Q.; Polito, C.A.; Lu, J.L.; Li, Q.S.; Liang, Y.R. Suppressive Effects of Tea Catechins on Breast Cancer. Nutrients 2016, 8, 458. [CrossRef] [PubMed]

15. Wang, Y.Q.; Lu, J.L.; Liang, Y.R.; Li, Q.S. Suppressive Effects of EGCG on Cervical Cancer. Molecules 2018, 23, 2334. [CrossRef] [PubMed]

16. Miyata, Y.; Matsuo, T.; Araki, K.; Nakamura, Y.; Sagara, Y.; Ohba, K.; Sakai, H. Anticancer effects of green tea and the underlying molecular mechanisms in bladder cancer. Medicines 2018, 5, 87. [CrossRef] [PubMed]

17. Ye, F.; Zhang, G.H.; Guan, B.X.; Xu, X.C. Suppression of esophageal cancer cell growth using curcumin, (-)-epigallocatechin-3-gallate and lovastatin. World J. Gastroenterol. 2012, 18, 126-135. [CrossRef] [PubMed]

18. Singh, B.N.; Shankar, S.; Srivastava, R.K. Green tea catechin, epigallocatechin-3-gallate (EGCG): Mechanisms, perspectives and clinical applications. Biochem. Pharmacol. 2011, 82, 1807-1821. [CrossRef]

19. Hou, Z.; Sang, S.; You, H.; Lee, M.J.; Hong, J.; Chin, K.V.; Yang, C.S. Mechanism of action of (-)-epigallocatechin-3-gallate: Auto-oxidation-dependent inactivation of epidermal growth factor receptor and direct effects on growth inhibition in human esophageal cancer KYSE 150 cells. Cancer Res. 2005, 65, 8049-8056. [CrossRef]

20. Yuan, J.M. Green tea and prevention of esophageal and lung cancers. Mol. Nutr. Food Res. 2011, 55, 886-904. [CrossRef]

21. Xie, Y.; Huang, S.; Su, Y. Dietary Flavonols Intake and Risk of Esophageal and Gastric Cancer: A Meta-Analysis of Epidemiological Studies. Nutrients 2016, 8, 91. [CrossRef] [PubMed]

22. Liu, L.; Hou, L.; Gu, S.; Zuo, X.; Meng, D.; Luo, M.; Zhang, X.; Huang, S.; Zhao, X. Molecular mechanism of epigallocatechin-3-gallate in human esophageal squamous cell carcinoma in vitro and in vivo. Oncol. Rep. 2015, 33, 297-303. [CrossRef] [PubMed]

23. Gao, Y.; Li, W.; Jia, L.; Li, B.; Chen, Y.C.; Tu, Y. Enhancement of (-)-epigallocatechin-3-gallate and theaflavin-3-3'-digallate induced apoptosis by ascorbic acid in human lung adenocarcinoma SPC-A-1 cells and esophageal carcinoma Eca-109 cells via MAPK pathways. Biochem. Biophys. Res. Commun. 2013, 438, 370-374. [CrossRef] [PubMed]

24. The Newcastle-Ottawa Scale (NOS) for Assessing the Quality of Nonrandomised Studies in Meta-Analyses. Available online: http://www.ohri.ca/programs/clinical_epidemiology/oxford.asp (accessed on 12 February 2019).

25. Gao, Y.T.; McLaughlin, J.K.; Blot, W.J.; Ji, B.T.; Dai, Q.; Fraumeni, J.F., Jr. Reduced risk of esophageal cancer associated with green tea consumption. J. Natl. Cancer Inst. 1994, 86, 855-858. [CrossRef] [PubMed]

26. Chen, Y.K.; Lee, C.H.; Wu, I.C.; Liu, J.S.; Wu, D.C.; Lee, J.M.; Goan, Y.G.; Chou, S.H.; Huang, C.T.; Lee, C.Y.; et al. Food intake and the occurrence of squamous cell carcinoma in different sections of the esophagus in Taiwanese men. Nutrition 2009, 25, 753-761. [CrossRef] [PubMed] 
27. Wang, Z.; Tang, L.; Sun, G.; Tang, Y.; Xie, Y.; Wang, S.; Hu, X.; Gao, W.; Cox, S.B.; Wang, J.S. Etiological study of esophageal squamous cell carcinoma in an endemic region: A population-based case control study in Huaian, China. BMC Cancer 2006, 6, 287. [CrossRef] [PubMed]

28. Nechuta, S.; Shu, X.O.; Li, H.L.; Yang, G.; Ji, B.T.; Xiang, Y.B.; Cai, H.; Chow, W.H.; Gao, Y.T.; Zheng, W. Prospective cohort study of tea consumption and risk of digestive system cancers: Results from the Shanghai Women's Health Study. Am. J. Clin. Nutr. 2012, 96, 1056-1063. [CrossRef] [PubMed]

29. Ren, J.S.; Freedman, N.D.; Kamangar, F.; Dawsey, S.M.; Hollenbeck, A.R.; Schatzkin, A.; Abnet, C.C. Tea, coffee, carbonated soft drinks and upper gastrointestinal tract cancer risk in a large United States prospective cohort study. Eur. J. Cancer 2010, 46, 1873-1881. [CrossRef]

30. Zheng, J.S.; Yang, J.; Fu, Y.Q.; Huang, T.; Huang, Y.J.; Li, D. Effects of green tea, black tea, and coffee consumption on the risk of esophageal cancer: A systematic review and meta-analysis of observational studies. Nutr. Cancer 2013, 65, 1-16. [CrossRef]

31. Sang, L.X.; Chang, B.; Li, X.H.; Jiang, M. Green tea consumption and risk of esophageal cancer: A meta-analysis of published epidemiological studies. Nutr. Cancer 2013, 65, 802-812. [CrossRef]

32. Zheng, P.; Zheng, H.M.; Deng, X.M.; Zhang, Y.D. Green tea consumption and risk of esophageal cancer: A meta-analysis of epidemiologic studies. BMC Gastroenterol. 2012, 12, 165. [CrossRef] [PubMed]

33. Chen, Z.; Chen, Q.; Xia, H.; Lin, J. Green tea drinking habits and esophageal cancer in southern China: A case-control study. Asian Pac. J. Cancer Prev. 2011, 12, 229-233. [PubMed]

34. Das, K.C.; Singh, S.; Pawar, G.; Masih, R.; Raju, N. Risk factors analysis of squamous cell carcinoma (scc) esophagus in North Indian females in tertiary care hospital: A case-control Study. Int. J. Recent Sci. Res. 2015, 6, 4661-4664.

35. Wani, I.; Parray, F.Q.; Wani, R.A.; Naqash, S.H.; Wani, K.A.; Malik, A.A.; Choudri, N.A.; Wani, M.A.; Khan, N.A.; Sheikh, T.A. Noon Chai and gastric cancer. Int. J. Case Rep. Imag. 2013, 4, 138-142. [CrossRef]

36. Wu, M.; Van't Veer, P.; Zhang, Z.F.; Wang, X.S.; Gu, X.P.; Han, R.Q.; Yang, J.; Zhang, X.F.; Liu, A.M.; Kok, F.J.; et al. A large proportion of esophageal cancer cases and the incidence difference between regions are attributable to lifestyle risk factors in China. Cancer Lett. 2011, 308, 189-196. [CrossRef] [PubMed]

37. Wu, M.; Liu, A.M.; Kampman, E.; Zhang, Z.F.; Van't Veer, P.; Wu, D.L.; Wang, P.H.; Yang, J.; Qin, Y.; $\mathrm{Mu}, \mathrm{L} . \mathrm{N}$.; et al. Green tea drinking, high tea temperature and esophageal cancer in high- and low-risk areas of Jiangsu Province, China: A population-based case-control study. Int. J. Cancer 2009, 124, 1907-1913. [CrossRef] [PubMed]

38. Yuan, J.M.; Sun, C.; Butler, L.M. Tea and cancer prevention: Epidemiological studies. Pharmacol. Res. 2011, 64, 123-135. [CrossRef] [PubMed]

39. Oze, I.; Matsuo, K.; Kawakita, D.; Hosono, S.; Ito, H.; Watanabe, M.; Hatooka, S.; Hasegawa, Y.; Shinoda, M.; Tajima, K.; et al. Coffee and green tea consumption is associated with upper aerodigestive tract cancer in Japan. Int. J. Cancer 2014, 135, 391-400. [CrossRef] [PubMed]

40. Zamora-Ros, R.; Lujan-Barroso, L.; Bueno-de-Mesquita, H.B.; Dik, V.K.; Boeing, H.; Steffen, A.; Tjonneland, A.; Olsen, A.; Bech, B.H.; Overvad, K.; et al. Tea and coffee consumption and risk of esophageal cancer: The European prospective investigation into cancer and nutrition study. Int. J. Cancer 2014, 135, 1470-1479. [CrossRef]

41. Tai, W.P.; Nie, G.J.; Chen, M.J.; Yaz, T.Y.; Guli, A.; Wuxur, A.; Huang, Q.Q.; Lin, Z.G.; Wu, J. Hot food and beverage consumption and the risk of esophageal squamous cell carcinoma: A case-control study in a northwest area in China. Medicine 2017, 96, e9325. [CrossRef]

42. Yang, X.; Ni, Y.; Yuan, Z.; Chen, H.; Plymoth, A.; Jin, L.; Chen, X.; Lu, M.; Ye, W. Very hot tea drinking increases esophageal squamous cell carcinoma risk in a high-risk area of China: A population-based case-control study. Clin. Epidemiol. 2018, 10, 1307-1320. [CrossRef] [PubMed]

43. Yu, C.; Tang, H.; Guo, Y.; Bian, Z.; Yang, L.; Chen, Y.; Tang, A.; Zhou, X.; Yang, X.; Chen, J.; et al. hot tea consumption and its interactions with alcohol and tobacco use on the risk for esophageal cancer: A population-based cohort study. Ann. Intern. Med. 2018, 168, 489-497. [CrossRef] [PubMed]

44. Meng, J.; Tong, Q.; Liu, X.; Yu, Z.; Zhang, J.; Gao, B. Epigallocatechin-3-gallate inhibits growth and induces apoptosis in esophageal cancer cells through the demethylation and reactivation of the p16 gene. Oncol. Lett. 2017, 14, 1152-1156. [CrossRef] [PubMed]

45. Liu, L.; Zuo, J.; Wang, G. Epigallocatechin-3-gallate suppresses cell proliferation and promotes apoptosis in Ec9706 and Eca109 esophageal carcinoma cells. Oncol. Lett. 2017, 14, 4391-4395. [CrossRef] [PubMed] 
46. Liu, L.; Ju, Y.; Wang, J.; Zhou, R. Epigallocatechin-3-gallate promotes apoptosis and reversal of multidrug resistance in esophageal cancer cells. Pathol. Res. Pract. 2017, 213, 1242-1250. [CrossRef] [PubMed]

47. Li, Z.G.; Shimada, Y.; Sato, F.; Maeda, M.; Itami, A.; Kaganoi, J.; Komoto, I.; Kawabe, A.; Imamura, M. Inhibitory effects of epigallocatechin-3-gallate on N-nitrosomethylbenzylamine-induced esophageal tumorigenesis in F344 rats. Int. J. Oncol. 2002, 21, 1275-1283. [CrossRef] [PubMed]

48. Song, S.; Krishnan, K.; Liu, K.; Bresalier, R.S. Polyphenon E inhibits the growth of human Barrett's and aerodigestive adenocarcinoma cells by suppressing cyclin D1 expression. Clin. Cancer Res. 2009, 15, 622-631. [CrossRef] [PubMed]

49. Chen, J. The effects of Chinese tea on the occurrence of esophageal tumors induced by $N$-nitrosomethylbenzylamine in rats. Prev. Med. 1992, 21, 385-391. [CrossRef]

50. Fang, M.Z.; Wang, Y.; Ai, N.; Hou, Z.; Sun, Y.; Lu, H.; Welsh, W.; Yang, C.S. Tea polyphenol (-)-epigallocatechin3-gallate inhibits DNA methyltransferase and reactivates methylation-silenced genes in cancer cell lines. Cancer Res. 2003, 63, 7563-7570. [PubMed]

51. Morse, M.A.; Kresty, L.A.; Steele, V.E.; Kelloff, G.J.; Boone, C.W.; Balentine, D.A.; Harbowy, M.E.; Stoner, G.D. Effects of theaflavins on N-nitrosomethylbenzylamine-induced esophageal tumorigenesis. Nutr. Cancer 1997, 29, 7-12. [CrossRef] [PubMed]

52. Wang, Z.Y.; Wang, L.D.; Lee, M.J.; Ho, C.T.; Huang, M.T.; Conney, A.H.; Yang, C.S. Inhibition of N-nitrosomethylbenzylamine-induced esophageal tumorigenesis in rats by green and black tea. Carcinogenesis 1995, 16, 2143-2148. [CrossRef] [PubMed]

53. Ni, J.; Guo, X.; Wang, H.; Zhou, T.; Wang, X. Differences in the effects of EGCG on chromosomal stability and cell growth between normal and colon cancer cells. Molecules 2018, 23, 788. [CrossRef] [PubMed]

54. Hanahan, D.; Weinberg, R.A. Hallmarks of cancer: The next generation. Cell 2011, 144, 646-674. [CrossRef] [PubMed]

55. Chiang, W.C.; Wong, Y.K.; Lin, S.C.; Chang, K.W.; Liu, C.J. Increase of MMP-13 expression in multi-stage oral carcinogenesis and epigallocatechin-3-gallate suppress MMP-13 expression. Oral Dis. 2006, 12, 27-33. [CrossRef] [PubMed]

56. Shimizu, M.; Deguchi, A.; Lim, J.T.; Moriwaki, H.; Kopelovich, L.; Weinstein, I.B. (-)-Epigallocatechin gallate and polyphenon $\mathrm{E}$ inhibit growth and activation of the epidermal growth factor receptor and human epidermal growth factor receptor-2 signaling pathways in human colon cancer cells. Clin. Cancer Res. 2005, 11, 2735-2746. [CrossRef] [PubMed]

57. Thakur, V.S.; Deb, G.; Babcook, M.A.; Gupta, S. Plant phytochemicals as epigenetic modulators: Role in cancer chemoprevention. AAPS J. 2014, 16, 151-163. [CrossRef] [PubMed]

58. Klutstein, M.; Nejman, D.; Greenfield, R.; Cedar, H. DNA methylation in cancer and aging. Cancer Res. 2016, 76, 3446-3450. [CrossRef]

59. Jones, P.A.; Baylin, S.B. The fundamental role of epigenetic events in cancer. Nat. Rev. Genet. 2002, 3, 415-428. [CrossRef]

60. Esteller, M. CpG island hypermethylation and tumor suppressor genes: A booming present, a brighter future. Oncogene 2002, 21, 5427-5440. [CrossRef]

61. Nguyen, C.T.; Gonzales, F.A.; Jones, P.A. Altered chromatin structure associated with methylation-induced gene silencing in cancer cells: Correlation of accessibility, methylation, MeCP2 binding and acetylation. Nucleic Acids Res. 2001, 29, 4598-4606. [CrossRef]

62. Rice, J.C.; Massey-Brown, K.S.; Futscher, B.W. Aberrant methylation of the BRCA1 CpG island promoter is associated with decreased BRCA1 mRNA in sporadic breast cancer cells. Oncogene 1998, 17, 1807-1812. [CrossRef] [PubMed]

63. Cheng, J.C.; Matsen, C.B.; Gonzales, F.A.; Ye, W.; Greer, S.; Marquez, V.E.; Jones, P.A.; Selker, E.U. Inhibition of DNA methylation and reactivation of silenced genes by zebularine. J. Natl. Cancer Inst. 2003, 95, 399-409. [CrossRef] [PubMed]

64. Christman, J.K. 5-Azacytidine and 5-aza-2'-deoxycytidine as inhibitors of DNA methylation: Mechanistic studies and their implications for cancer therapy. Oncogene 2002, 21, 5483-5495. [CrossRef] [PubMed]

65. Bender, C.M.; Pao, M.M.; Jones, P.A. Inhibition of DNA methylation by 5-aza-2'-deoxycytidine suppresses the growth of human tumor cell lines. Cancer Res. 1998, 58, 95-101. [PubMed]

66. Ahmad, N.; Cheng, P.; Mukhtar, H. Cell cycle dysregulation by green tea polyphenol epigallocatechin-3-gallate. Biochem. Biophys. Res. Commun. 2000, 275, 328-334. [CrossRef] [PubMed] 
67. Gupta, S.; Hussain, T.; Mukhtar, H. Molecular pathway for (-)-epigallocatechin-3-gallate-induced cell cycle arrest and apoptosis of human prostate carcinoma cells. Arch. Biochem. Biophys. 2003, 410, 177-185. [CrossRef]

68. Chung, J.Y.; Park, J.O.; Phyu, H.; Dong, Z.; Yang, C.S. Mechanisms of inhibition of the Ras-MAP kinase signaling pathway in $30.7 \mathrm{~b}$ Ras 12 cells by tea polyphenols (-)-epigallocatechin-3-gallate and theaflavin-3,3'-digallate. FASEB J. 2001, 15, 2022-2024. [CrossRef] [PubMed]

69. Bode, A.M.; Dong, Z. Signal transduction pathways: Targets for chemoprevention of skin cancer. Lancet Oncol. 2000, 1, 181-188. [CrossRef]

70. Pan, J.; Zhang, Q.; Xiong, D.; Vedell, P.; Yan, Y.; Jiang, H.; Cui, P.; Ding, F.; Tichelaar, J.W.; Wang, Y.; et al. Transcriptomic analysis by RNA-seq revealspathway as key regulator that green tea may rely on to inhibit lung tumorigenesis. Mol. Carcinog. 2014, 53, 19-29. [CrossRef]

71. Chung, J.Y.; Huang, C.; Meng, X.; Dong, Z.; Yang, C.S. Inhibition of activator protein 1 activity and cell growth by purified green tea and black tea polyphenols in H-ras-transformed cells: Structure-activity relationship and mechanisms involved. Cancer Res. 1999, 59, 4610-4617.

72. Dong, Z.; Ma, W.; Huang, C.; Yang, C.S. Inhibition of tumor promoter-induced activator protein 1 activation and cell transformation by tea polyphenols, (-)-epigallocatechin gallate, and theaflavins. Cancer Res. 1997, 57, 4414-4419. [PubMed]

73. Negri, A.; Naponelli, V.; Rizzi, F.; Bettuzzi, S. Molecular Targets of Epigallocatechin-Gallate (EGCG): A Special Focus on Signal Transduction and Cancer. Nutrients 2018, 10, 1936. [CrossRef] [PubMed]

74. Wagner, E.F.; Nebreda, A.R. Signal integration by JNK and p38 MAPK pathways in cancer development. Nat. Rev. Cancer 2009, 9, 537-549. [CrossRef] [PubMed]

75. Li, Z.G.; Shimada, Y.; Sato, F.; Maeda, M.; Itami, A.; Kaganoi, J.; Komoto, I.; Kawabe, A.; Imamura, M. Promotion effects of hot water on N-nitrosomethylbenzylamine-induced esophageal tumorigenesis in F344 rats. Oncol. Rep. 2003, 10, 421-426. [CrossRef] [PubMed]

76. An, Z.; Qi, Y.; Huang, D.; Gu, X.; Tian, Y.; Li, P.; Li, H.; Zhang, Y. EGCG inhibits Cd ${ }^{(2+)}$-induced apoptosis through scavenging ROS rather than chelating $\mathrm{Cd}^{(2+)}$ in HL-7702 cells. Toxicol. Mech. Methods 2014, 24, 259-267. [CrossRef] [PubMed]

77. Kanwar, J.; Taskeen, M.; Mohammad, I.; Huo, C.; Chan, T.H.; Dou, Q.P. Recent advances on tea polyphenols. Front. Biosci. 2012, 4, 111-131. [CrossRef]

78. Frei, B.; Higdon, J.V. Antioxidant activity of tea polyphenols in vivo: Evidence from animal studies. J. Nutr. 2003, 133, 3275s-3284s. [CrossRef] [PubMed]

79. Sriram, N.; Kalayarasan, S.; Sudhandiran, G. Epigallocatechin-3-gallate augments antioxidant activities and inhibits inflammation during bleomycin-induced experimental pulmonary fibrosis through Nrf2-Keap1 signaling. Pulm. Pharmacol. Ther. 2009, 22, 221-236. [CrossRef] [PubMed]

80. Surh, Y.J.; Kundu, J.K.; Na, H.K. Nrf2 as a master redox switch in turning on the cellular signaling involved in the induction of cytoprotective genes by some chemopreventive phytochemicals. Planta Med. 2008, 74, 1526-1539. [CrossRef]

81. Yang, C.S.; Wang, X.; Lu, G.; Picinich, S.C. Cancer prevention by tea: Animal studies, molecular mechanisms and human relevance. Nat. Rev. Cancer 2009, 9, 429-439. [CrossRef]

82. Li, H.; Jiang, N.; Liu, Q.; Gao, A.; Zhou, X.; Liang, B.; Li, R.; Li, Z.; Zhu, H. Topical treatment of green tea polyphenols emulsified in carboxymethyl cellulose protects against acute ultraviolet light B-induced photodamage in hairless mice. Photochem. Photobiol. Sci. 2016, 15, 1264-1271. [CrossRef] [PubMed]

83. Saha, P.; Das, S. Elimination of deleterious effects of free radicals in murine skin carcinogenesis by black tea infusion, theaflavins and epigallocatechin gallate. Asian Pac. J. Cancer Prev. 2002, 3, 225-230. [PubMed]

84. Sun, C.L.; Yuan, J.M.; Lee, M.J.; Yang, C.S.; Gao, Y.T.; Ross, R.K.; Yu, M.C. Urinary tea polyphenols in relation to gastric and esophageal cancers: A prospective study of men in Shanghai, China. Carcinogenesis 2002, 23, 1497-1503. [CrossRef] [PubMed]

85. Li, G.X.; Chen, Y.K.; Hou, Z.; Xiao, H.; Jin, H.; Lu, G.; Lee, M.J.; Liu, B.; Guan, F.; Yang, Z.; et al. Pro-oxidative activities and dose-response relationship of (-)-epigallocatechin-3-gallate in the inhibition of lung cancer cell growth: A comparative study in vivo and in vitro. Carcinogenesis 2010, 31, 902-910. [CrossRef] [PubMed]

86. Spechler, S.J.; Sharma, P.; Souza, R.F.; Inadomi, J.M.; Shaheen, N.J. American gastroenterological association medical position statement on the management of barrett's esophagus. Gastroenterology 2011, 140, 1084-1091. [CrossRef] [PubMed] 
87. Joe, A.K.; Schnoll-Sussman, F.; Bresalier, R.S.; Abrams, J.A.; Hibshoosh, H.; Cheung, K.; Friedman, R.A.; Yang, C.S.; Milne, G.L.; Liu, D.D.; et al. Phase Ib Randomized, Double-blinded, placebo-controlled, dose escalation study of polyphenon e in patients with barrett's esophagus. Cancer Prev. Res. 2015, 8, 1131-1137. [CrossRef] [PubMed]

88. Zhao, H.; Xie, P.; Li, X.; Zhu, W.; Sun, X.; Sun, X.; Chen, X.; Xing, L.; Yu, J. A prospective phase II trial of EGCG in treatment of acute radiation-induced esophagitis for stage III lung cancer. Radiother. Oncol. 2015, 114, 351-356. [CrossRef]

89. Andrici, J.; Eslick, G.D. Hot Food and Beverage Consumption and the Risk of Esophageal Cancer: A Meta-Analysis. Am. J. Prev. Med. 2015, 49, 952-960. [CrossRef]

90. Okaru, A.O.; Rullmann, A.; Farah, A.; Gonzalez de Mejia, E.; Stern, M.C.; Lachenmeier, D.W. Comparative oesophageal cancer risk assessment of hot beverage consumption (coffee, mate and tea): The margin of exposure of PAH vs. very hot temperatures. BMC Cancer 2018, 18, 236. [CrossRef]

91. Rasool, S.; Ganai, B.A.; Kadla, S.A.; Ahanger, A.G.; Qazi, F.; Khan, T.; Rasool, V.; Masood, A. The ECRG1 290Arg/Gln polymorphism is related to risk of esophageal squamous cell carcinoma in Kashmir. Asian Pac. J. Cancer Prev. 2011, 12, 265-269.

92. Meng, X.; Sang, S.; Zhu, N.; Lu, H.; Sheng, S.; Lee, M.J.; Ho, C.T.; Yang, C.S. Identification and characterization of methylated and ring-fission metabolites of tea catechins formed in humans, mice, and rats. Chem. Res. Toxicol. 2002, 15, 1042-1050. [CrossRef] [PubMed]

93. Cai, Z.Y.; Li, X.M.; Liang, J.P.; Xiang, L.P.; Wang, K.R.; Shi, Y.L.; Yang, R.; Shi, M.; Ye, J.H.; Lu, J.L.; et al. Bioavailability of Tea Catechins and Its Improvement. Molecules 2018, 23, 2346. [CrossRef] [PubMed]

94. Niedzwiecki, A.; Roomi, M.W.; Kalinovsky, T.; Rath, M. Anticancer efficacy of polyphenols and their combinations. Nutrients 2016, 8, 552. [CrossRef] [PubMed]

95. Schroeder, A.C.; Xiao, H.; Zhu, Z.; Li, Q.; Bai, Q.; Wakefield, M.R.; Mann, J.D.; Fang, Y. A Potential role for green tea as a radiation sensitizer for prostate cancer. Pathol. Oncol. Res. 2017, 25, 263-268. [CrossRef]

96. Zhang, G.; Wang, Y.; Zhang, Y.; Wan, X.; Li, J.; Liu, K.; Wang, F.; Liu, K.; Liu, Q.; Yang, C.; et al. Anti-cancer activities of tea epigallocatechin-3-gallate in breast cancer patients under radiotherapy. Curr. Mol. Med. 2012, 12, 163-176. [CrossRef]

97. Lambert, J.D.; Sang, S.; Hong, J.; Kwon, S.J.; Lee, M.J.; Ho, C.T.; Yang, C.S. Peracetylation as a means of enhancing in vitro bioactivity and bioavailability of epigallocatechin-3-gallate. Drug Metab. Dispos. 2006, 34, 2111-2116. [CrossRef]

98. Chiou, Y.S.; Ma, N.J.; Sang, S.; Ho, C.T.; Wang, Y.J.; Pan, M.H. Peracetylated (-)-epigallocatechin-3-gallate (AcEGCG) potently suppresses dextran sulfate sodium-induced colitis and colon tumorigenesis in mice. J. Agric. Food Chem. 2012, 60, 3441-3451. [CrossRef]

99. Hardefeldt, H.A.; Cox, M.R.; Eslick, G.D. Association between human papillomavirus (HPV) and oesophageal squamous cell carcinoma: A meta-analysis. Epidemiol. Infect. 2014, 142, 1119-1137. [CrossRef]

100. Yamada, S.; Tsukamoto, S.; Huang, Y.; Makio, A.; Kumazoe, M.; Yamashita, S.; Tachibana, H. Epigallocatechin-3-O-gallate up-regulates microRNA-let-7b expression by activating 67-kDa laminin receptor signaling in melanoma cells. Sci. Rep. 2016, 6, 19225. [CrossRef]

101. Toden, S.; Tran, H.M.; Tovar-Camargo, O.A.; Okugawa, Y.; Goel, A. Epigallocatechin-3-gallate targets cancer stem-like cells and enhances 5-fluorouracil chemosensitivity in colorectal cancer. Oncotarget 2016, 7, 16158-16171. [CrossRef]

102. Zhou, H.; Manthey, J.; Lioutikova, E.; Yang, W.; Yoshigoe, K.; Yang, M.Q.; Wang, H. The up-regulation of Myb may help mediate EGCG inhibition effect on mouse lung adenocarcinoma. Hum. Genom. 2016, 10 (Suppl. S2), 19. [CrossRef] [PubMed]

103. Hu, N.; Wang, C.; Clifford, R.J.; Yang, H.H.; Su, H.; Wang, L.; Wang, Y.; Xu, Y.; Tang, Z.Z.; Ding, T.; et al. Integrative genomics analysis of genes with biallelic loss and its relation to the expression of mRNA and micro-RNA in esophageal squamous cell carcinoma. BMC Genom. 2015, 16, 732. [CrossRef]

104. Fujiki, H.; Watanabe, T.; Sueoka, E.; Rawangkan, A.; Suganuma, M. Cancer prevention with green tea and its principal constituent, EGCG: From early investigations to current focus on human cancer stem cells. Mol. Cells 2018, 41, 73-82. [PubMed]

105. Nishimura, N.; Hartomo, T.B.; Pham, T.V.; Lee, M.J.; Yamamoto, T.; Morikawa, S.; Hasegawa, D.; Takeda, H.; Kawasaki, K.; Kosaka, Y.; et al. Epigallocatechin gallate inhibits sphere formation of neuroblastoma BE(2)-C cells. Environ. Health Prev. Med. 2012, 17, 246-251. [CrossRef] [PubMed] 
106. Mineva, N.D.; Paulson, K.E.; Naber, S.P.; Yee, A.S.; Sonenshein, G.E. Epigallocatechin-3-gallate inhibits stem-like inflammatory breast cancer cells. PLoS ONE 2013, 8, e73464. [CrossRef] [PubMed]

107. Chen, Y.; Wang, X.Q.; Zhang, Q.; Zhu, J.Y.; Li, Y.; Xie, C.F.; Li, X.T.; Wu, J.S.; Geng, S.S.; Zhong, C.Y.; et al. (-)-Epigallocatechin-3-gallate inhibits colorectal cancer stem cells by suppressing Wnt/beta-catenin pathway. Nutrients 2017, 9, 572. [CrossRef]

108. Kumazoe, M.; Takai, M.; Hiroi, S.; Takeuchi, C.; Yamanouchi, M.; Nojiri, T.; Onda, H.; Bae, J.; Huang, Y.; Takamatsu, K.; et al. PDE3 inhibitor and EGCG combination treatment suppress cancer stem cell properties in pancreatic ductal adenocarcinoma. Sci. Rep 2017, 7, 1917. [CrossRef]

109. Chani, B.; Puri, V.; Chander Sobti, R.; Puri, S. Epigallocatechin gallate inhibits mouse mesenchymal stem cell differentiation to adipogenic lineage. J. Stem Cells Regen. Med. 2016, 12, 16-24.

110. Bennett, W.P.; Hollstein, M.C.; Metcalf, R.A.; Welsh, J.A.; He, A.; Zhu, S.M.; Kusters, I.; Resau, J.H.; Trump, B.F.; Lane, D.P.; et al. p53 mutation and protein accumulation during multistage human esophageal carcinogenesis. Cancer Res. 1992, 52, 6092-6097.

111. Liu, X.; Zhang, M.; Ying, S.; Zhang, C.; Lin, R.; Zheng, J.; Zhang, G.; Tian, D.; Guo, Y.; Du, C.; et al. Genetic alterations in esophageal tissues from squamous dysplasia to carcinoma. Gastroenterology 2017, 153, $166-177$. [CrossRef]

112. Shimada, H. p53 molecular approach to diagnosis and treatment of esophageal squamous cell carcinoma. Ann. Gastroenterol. Surg. 2018, 2, 266-273. [CrossRef] [PubMed]

113. Zhao, Z.; Wang, P.; Gao, Y.; He, J. The high expression instead of mutation of p53 is predictive of overall survival in patients with esophageal squamous-cell carcinoma: A meta-analysis. Cancer Med. 2017, 6, 54-66. [CrossRef] [PubMed]

114. Kandioler, D.; Schoppmann, S.F.; Zwrtek, R.; Kappel, S.; Wolf, B.; Mittlbock, M.; Kuhrer, I.; Hejna, M.; Pluschnig, U.; Ba-Ssalamah, A.; et al. The biomarker TP53 divides patients with neoadjuvantly treated esophageal cancer into 2 subgroups with markedly different outcomes. A p53 Research Group study. J. Thorac. Cardiovasc. Surg. 2014, 148, 2280-2286. [CrossRef] [PubMed]

115. Huang, C.Y.; Han, Z.; Li, X.; Xie, H.H.; Zhu, S.S. Mechanism of EGCG promoting apoptosis of MCF-7 cell line in human breast cancer. Oncol. Lett. 2017, 14, 3623-3627. [CrossRef] [PubMed]

116. Xu, W.; Mezencev, R.; Kim, B.; Wang, L.; McDonald, J.; Sulchek, T. Cell stiffness is a biomarker of the metastatic potential of ovarian cancer cells. PLOS ONE 2012, 7, e46609. [CrossRef] [PubMed]

117. Suganuma, M.; Takahashi, A.; Watanabe, T.; Iida, K.; Matsuzaki, T.; Yoshikawa, H.Y.; Fujiki, H. Biophysical Approach to Mechanisms of Cancer Prevention and Treatment with Green Tea Catechins. Molecules 2016, 21, 1566. [CrossRef]

118. Khan, N.; Mukhtar, H. Tea Polyphenols in Promotion of Human Health. Nutrients 2019, 11, 39. [CrossRef]

119. Boehm, K.; Borrelli, F.; Ernst, E.; Habacher, G.; Hung, S.K.; Milazzo, S.; Horneber, M. Green tea (Camellia sinensis) for the prevention of cancer. Cochrane Database Syst. Rev. 2009, 3, Cd005004. [CrossRef]

120. Liang, Y.R.; Lu, J.L.; Shang, S.L. Effects of gibberellins on chemical composition and quality of tea (Camellia sinensis L.). J. Sci. Food Agric. 1996, 72, 411-414. [CrossRef]

(C) 2019 by the authors. Licensee MDPI, Basel, Switzerland. This article is an open access article distributed under the terms and conditions of the Creative Commons Attribution (CC BY) license (http:/ / creativecommons.org/licenses/by/4.0/). 